\title{
Gender, meta-discourse and stylistic appropriateness in English writing
}

\section{Cüneyt DEMİR}

\begin{abstract}
APA: Demir, C. (2019). Gender, meta-discourse and stylistic appropriateness in English writing.
\end{abstract} RumeliDE Dil ve Edebiyat Araşttrmaları Dergisi, (16), 148-159. DOI: 10.2900o/rumelide.616912

\begin{abstract}
Academic writing is important for writers to persuade readers on their claims, which is why the literature is full of studies aiming to improve academic writing and making suggestions regarding how the writing style should be. However, the missing point as to this important issue is that they largely investigate the issue of writing in terms of linguistic, and overlook the extralinguistic factors, or merely investigate a single issue without considering its ensuing ramifications; for example, gender effect on discourse. On the other hand, this study investigates gender effect together with its possible impact on the change of discourse and the style of writing which is crucial to have an impact on the audience. Also, this study aims to draw attention on extralinguistic factors affecting academic writing. This study showed that academic writing is not independent of the effect of gender because the discourse style of a female and male author seems to be different from each other. Furthermore, apart from the effect of gender, extralinguistic factors like social and intrapersonal parameters play an important role in determining the discourse of the author, and accordingly the writing style. This study calls further studies in order to reveal rhetoric differences and the effect of gender on more specific linguistic components.
\end{abstract}

Keywords: Gender, discourse, academic writing, style.

\section{Akademik yazımda cinsiyet, söylem ve tarz}

\section{Özet}

\begin{abstract}
Akademik yazım kabiliyeti, yazarın yazdıkları konusunda okuyucuları ikna etmede oldukça önemlidir. Bundan dolayı, literatür akademik yazımın nasıl geliştirilebileceği ve nasıl olması gerektiği konusunda çalışmalarla doludur. Oysaki çoğu çalışma akademik yazım konusunu dil bilgisel konuda ele almakta ve dil bilgisel olmayan diğer konuları göz ardı etmektedir ya da konuyu muhtemel etkilenebilecek diğer açıları düşünmeden tek bir açıdan ele almaktadır. Bu çalışma cinsiyetin söylem üzerindeki etkisini ve dolayısıyla yazma sitili nasıl değiştirebileceğini incelemekte ve dil bilgisel etkenler olmayan cinsiyet, sosyal ve kişilik faktörlerinin yazma sitili üzerindeki etkisini araştırmış ve bunların ne düzeyde etkili olduklarını ortaya çalışmıştır. Literatür, kadın ve erkek arasında söylem farklılıkları olduğunu ortaya koyduğun cinsiyetin yazımda söylem üzerinde etkili olduğunu söyleyebiliriz. Ayrıca, sosyal ve kişisel parametrelerin de yazarın söylem şeklini etkilediği anlaşılmaktadır. Retorik farklılıklarını cinsiyet kavramı üzerinden veya dil bilgisel olmayan etkenler üzerinden araştırmak isteyen yazarlar daha spesifik konuları incelemeleri faydalı olacaktır.
\end{abstract}

Anahtar kelimeler: Cinsiyet, söylem, akademik yazım, tarz.

1 Dr. Öğr. Üyesi, Siirt Üniversitesi, Yabancı Diller Yüksekokulu, Mütercim-Tercümanlık Bölümü (Siirt, Türkiye), DOI: 10.2900o/rumelide.616912]. 


\section{Introduction}

Writing never ceased to be a crucial skill for writers, and sustains its importance more than ever. You are required to express yourself or to carry knowledge onto somebody or somewhere else, the safest way will undoubtedly be writing thanks to its protracted endurance and exact same recording feature. Though it may be erratic in its script, (i.e. cuneiform, logographic, syllabic, or alphabetic) and a multifaceted phenomenon, this would not lessen its power of expression which is indispensable for people's lives.

A pile of information would await you when any request regarding the features of academic writing was put in the literature; only a scrap of information is needed though. This study briefly rows the features of academic writing and what a writer should keep in mind before starting writing. Another factor is the influence of language used in the manuscript; discourse is the issue vastly investigated by researchers. The literature underscores the possible things that affect the discourse, one of which is gender. In other words, gender has an impact on the discourse; hence it may change the style of the writing. In short, the literature review highly mentions gender, discourse, and academic writing separately; accordingly, this study draws a triangle and places gender, discourse, and the output (the final language as a result of gender-discourse reaction). This theoretical study aims to correlate the effect of gender and the language that the writer uses, and show factors that affect stylistic appropriateness of academic writing. This study also has a purpose of garnering diverse views on the importance of discourse, and submitting concisely the requisites of scholarly writing. This study starts with defining writing in English, and then the important aspects of academic writing in English, the relation between discourse and academic writing, challenges for writers in deciding the discoursal features of their manuscripts, gender effect, and finally appropriate style of academic writing together with linguistic and extra-linguistic factors.

\section{Writing in English}

The proliferation of colleges, universities and other educational institutions in the past several decades has made academic writing a fact of life for scholars, and since then the issue of scholarly writing has widely been a topic of interest for particularly non-native writers. Accordingly quite a few prominent researchers concerned themselves about the issue from different points of view; for example, while Hinkel (2003) stated the importance of grammatical competence in academic writings, researchers such as Allison, Cooley, Lewkowicz and Nunan (1998) discussed the problems in organization of the script on a macro and micro levels. Similarly, some other scholars argued the impact of L2 writing competence over L1 writing skill (cf. Shi, 2002; and Hirose, 2003), and specifically investigated the phenomenon of writing. For instance, Bailey (2006) divided academic writing into three: the writing process, elements of writing, and accuracy.

At the very start, prior to starting writing, the writer should be aware of that academic writing requires a cognitive process; therefore, the writer is to be braced for complete meta-cognitive awareness. Furthermore, academic writing is not an arbitrary, hence instantaneous work, but a serious work that needs a thorough preliminary preparation. On the course of writing, the importance of structural arrangements such as opening paragraphs, cohesion, coherence, restatements, variation in sentence length etc. gains ground to construct the style of the writing, that is, discourse. Structural arrangements remain the foremost feature of writing in creating a penetrative impression over the reader. 
Argentina (2013) underlined five types of competence for qualified L2 academic writing, which are linguistic competence, discourse competence, pragmatic competence, strategic competence, and intercultural competence. Academic writing is not an issue restricted to a certain sphere of people; therefore, you may encounter different views about the fundamental of academic writing. However, this study summarized the literature as to the linguistic elements affecting academic writing, and concluded that out of seven pillars for academic writing -namely complexity, formality, precision, objectivity, explicitness, hedging, and responsibility- three come into prominence: clarity, objectivity, and accuracy.

\subsection{Clarity, objectivity, and accuracy in scholar writing}

For an effective reading, the text meaning should be clarified (Bailey, 2011). Therefore, writers are to give primacy on clarity but they should evade any initiative of constructing sophisticated texts unless they reach to a certain degree in language competence and proficiency because it might lead to ill-formed sentences, hence disrupt the meaning and clarity. Similarly, Bailey (2006) states that the best thing that an author should do if s/he is indefinite about how to advance in terms of clarity is to wait patiently until being an established writer; without of which it would be difficult to transmit personal goals to readers in a clear way. Hence, the audience will clearly understand what an author would like to be acquired from his/her writing. Expanding manuscript clarity at the word and sentence level is a necessary process of editing (Richards \& Miller, 2005); however, being clear in writings is not something only with word choice and sentence constructing, but also with graphs, tables, and organisational layout of a scientific writing. Tables should be clear enough for a reader to understand the point that it tells, and graphs need to be visible to make sure that they are clear to audience. The framework of a scientific writing is mostly expected to be bottom-up or deductive. Shortly, while writing for the academic world, authors are to make their definitions clear (Fulwiler, 2002).

Similarly, one of the forefront objectives of scientific writings is to make the audience believe the author's utterances, and then persuade them to stick to the trueness of the utterances in order to spread the information. Fulwiler (2002) asserted that the writer should be completely objective and impartial when conducting research, and s/he must strictly adhere to the code of objectivity. In addition to that the issue of objectivity is problematic; it is at the hub of numerous challenges to the academic tradition (Richards \& Miller, 2005). Richard and Miller (2005) indicated that the writer can achieve impartiality through linguistic devices such as inclusion of passive voices, and plural pronouns, or $\mathrm{s} / \mathrm{he}$ can provide statistical (quantitative) accounts. The characterization of a good scientific writing is commensurate with its objectivity, which means that a proper scientific text must present a balanced discussion of various views and value judgements (Smyth, 1996). Smyth further claimed that "when you write an academic paper, unless you attribute an opinion to someone else, it is understood to be your own. Phrases such as in my opinion' or 'I think,' therefore, are superfluous and a waste of words” (pp. 2-3).

Apart from clarity and objectivity, accuracy is another crucial component of academic writing, through which the writer provides credibility for his/her claims. Accuracy can be evaluated through proofreadings and other content-wise peer reviewers. Whereas proof-readings are realised in order to detect any language related problems, content-wise peer reviews are applied to seek any content-related misdirection on the topic. As known, writing is a multidimensional process; that is, there are a lot disparate factors that could affect the writing process. Accuracy is simply one of the factors that could negatively disrupt the credibility of writing. It is true that while all kinds of writing tasks carry high expectations of accuracy, the expectation of accuracy is even stricter for academic writings than any other types of writings; because any deficiency in accuracy with an academic text will not be acceptable 
for the writer's credibility. That is because the importance of accuracy in academic world cannot be underestimated for on-demand writing purposes (Richards \& Miller, 2005). Native writers may come across with contextual accuracy problems in their articles; however the matter is double-fold for nonnative writers because they may have contextual accuracy problems as well as the accuracy of language. Both editors and peer-reviewers examine the academic submissions to ensure authors' accuracy of scholarly and scientific knowledge. However, the accuracy problem of language is much more common among non-native writers; as can be guessed.

\section{Academic writing and metadiscourse}

As well as structural and mechanical prerequisites such as objectivity, accuracy, and clarity, a scientific text demands other additions to provide a reader engagement, persuasion, and credibility, which is discoursal features of the language. Although it was seen a recent term, metadiscourse has a long past that that goes back to 1959 in which Zellig Harris (the owner of the term metadiscourse) proposed a way of understanding communicative language representing a speaker's or writer's attempts to guide a receiver's perception of a written or spoken text (Hyland, 2005). Later on, the concept of metadiscourse was developed further by prominent linguists like Crismore (1989), Vande Kopple (1985) and Williams (1981) who collected a range of discoursal devices (particularly on hedging and boosting) to investigate the effect of them on interlocutors' or receivers' receptions. It is a well establish fact by linguists that awareness of language or language competency has greatly changed from the focus of language itself as form and structure to language use as pragmatics. What was crucial in the past was crucial again; however the tendency of language had converted its face from heavy contented grammar books to the streets, where the language is for communication. A marked milestone in language teaching, also be recognized as communicative language teaching, belonged to Hymes (1974) who steered the notion of communicative competence and the focus of syllabus design away from the grammar based syllabus for an effort to identify the nature of a communication based syllabus (Munby, 1978). Apparently, differences remains between grammar based and communicative based syllabuses. In other words, the notion of communicative competence is based primarily on native speaker's abilities while grammar competence -once upon a time was linguists' primary aim- is something with reading comprehension. It is explicit that the use of even the most basic items such as hi, thanks or good evening used in a syllabus can possibly bring about cross-cultural misunderstanding owing to pragmatic and communicative differences between languages.

On contrary to the widespread thought, communication is much more than just exchanging the words semantically between interlocutors; it embodies assumptions, personalities, and attitudes. Furthermore, the utterances may have implicit meanings underlying their overt expressions. The use of linguistic components such as adverbs, adjectives, imperatives, evaluative commentary, etc. in a rhetoric manner open new windows on discovering writer's real or intended message submitted to the reader. Therefore, if these rhetoric features were removed, the content would possibly become less interesting, less personal and less easy to follow. Therefore, offering these metadiscourse features systematically provides readers with access to the insight of the content and allows readers align themselves with the writer (Hyland, 2005). Again, with a judicious use of metadiscourse, a writer is able to alter an uneventful text into a coherent prose; furthermore the writer can relate the text to a given context and transmit his/her credibility, personality, audience-sensitivity to the message. It should not be missed that writing is a multifaceted skill that requires keeping several spontaneous processes under consideration in order to interpret the meaning in a way that will not disrupt the intended meaning. A writer's positions, interests, perspectives and values are not always easy to convey to the readers through 
plain texts because they are not always there standing to convey the message. In order for a successful audience communication, comprehension or involvement, there must be a mutual act of understanding between producers and receivers. And, to construct that mutual act of understanding is a tough job from the aspect of writer. To be able to achieve the desired communication, it is expected to use words more than their unbending and dormant meanings, which is one of the main functions of metadiscourse devices.

The book of Metadiscourse: Exploring Interaction in Writing shows us that rhetoric is a concept increasingly important in compositions. The term has been studied from different aspects in order to shed light on its importance on varied fields; for example Schiffrin (1980) studied metadiscourse in casual conversations; Norrick (2001) in oral narratives; Crismore and Farnsworth (1990) in school textbooks; Hyland (2000) in undergraduate textbooks; Bunton (1999), Hyland (2004), and Swales (1990) in postgraduate dissertations; Fuertes-Olivera et al., (2001) in advertising slogans; Hyland (1998) in company annual reports; Taavitsainen (1999) in medieval medical writings; and Atkinson (1999) in scientific discourse from the late seventeenth century. In other words, metadiscourse has a vast area of research from formal academic writings to informal slogans. Due to the fact that writing has an overarching significance in academic genre, the use of metadiscourse devices is an important mean of supporting an authorial position, facilitating communication, increasing readability, and building a connection with the audience (Hyland, 2005). Furthermore, it is through rhetorical devices that become possible to present a writer's real opinions, evaluations and interests in a text by refining possible reactions that a reader could develop. According to Ong (1983), rhetoric was named differently through its long history. Since Aristotle's book rhetoric, it has been referred as one of the most vital components of all academic issues. The notion of rhetoric inclined to carry adverse connotation for formal proof in the recent past because it was thought that it suggested unscrupulous manipulation and coercion but nowadays it is one of the central concepts to whom working in written communication and text analysis (Hyland, 2005). Mauranen (1993) underlined this importance and stated that

\begin{abstract}
"The study of rhetoric has been rediscovered not only as a means of improving efficiency in verbal presentation, but as an analytical tool that can be used by different disciplines for uncovering certain aspects of discourse (p. 20).”
\end{abstract}

The close relationship between rhetoric, persuasion, and academic writing has been an issue studied from different aspects. Rhetoric is essential for making claims, creating a sense to the reader, stylistic appropriateness, organization of the argument, internal consistency, clarity of the claim, and surely persuasion. Therefore, in order to have an effective argumentative writing which aims to persuade that your ideas are accurate and valid, rhetoric must be used in a careful way. Now that rhetoric is the art of persuasion, a writer must be aware of the knowledge on how to use main rhetorical styles effectively. The literature shows that there are three styles of rhetoric that a writer needs to know to be an effective writer, which are Ethos, Pathos, and Logos. They are the terms coined and categorized by Greek philosopher Aristotle, which are summarized as follows.

Logos are rational appeals reasoning ability of readers. This is the place in which writer use the sense of logic in order to persuade the reader over the argued issue. It refers to the internal consistency of claims through inductive and deductive reasoning. The writer may use concrete evidences to support his/her arguments. Logos include case studies, facts, statistics, experiments, analogies, anecdotes, logical reasoning, and authority voices (Van, 2015). Every claim that an academic writer make should carry rationality inside it so that the reader may find it plausible and reasonable. A writer will have quite a few difficulties to persuade the reader on any illogical claim even if he/she asserts that he/she has proofs. 
Therefore, a scholar should use logos properly in order to avoid any logical fallacies while composing a text.

The word ethos means "character" in Greek, which is a word that refers to the trustworthiness of a writer. Different from logos which cover rationality, ethos is in association with credibility or other ethical appeals. One of the main problems that a writer could face in academic world is the matter of proving himself/herself to the reader that you are the one worth listening to. Therefore, if a writer carries ethos into effect successfully, they may function as credibility appeals by catching readers' respects towards the argumentation as well as the writer himself/herself. The words that can define ethos are credibility, reliability, trustworthiness, reliable sources, and fairness (Van, 2015). A writer's reputation is an issue which may be categorized under ethos. Hauser (1986) stated that ethos should not be regarded as a static attribute or quality, but as something dynamic which changes in each time.

Pathos are emotional appeals like belief in fairness, love, pity, greed, revenge, etc. As aforementioned, one of the features of an academic writing is to have objectivity. Any affective focuses or appeals will certainly be seen as a setback of the text as well as the writer's himself/herself. However, what is told through Pathos is that the scientific text should focus on readers' characterization, i.e. inner worlds. Therefore, pathos is related to the words sympathy, pathetic, affinity, compassion, and empathy. Shortly, Pathos can be defined as art of persuasion by referring to the reader's emotions. This type of convincing is largely used in advertisements, or charity organisations. Though, it is possible to see the traces of pathos in academic writings because some scientific texts need to touch to an audience's values, needs, and emotional sensibilities in order to persuade him/her. On the other hand, pathos must be used properly; for example, in order to support a truth, or reveal a reality, but not to misrepresent an issue or frighten people (Weida \& Stolley, 2013).

Formerly it was widespread that academia, which is a place for directness, had not place for rhetoric, but over the last decades we know that academic writing has gradually turned its face from traditional tags as rigid, impersonal, and structured form of discourse and come to be as a convincing endeavour involving interaction between readers and writers (Hyland, 2005). Extra-logical or extra-factual expectations on arguing subjects restrict a writer's workplace, and most of the time this ends with a parochial paper that cannot provide ethos, pathos, and logos. However, the primary and foremost purpose of an academic writing is to stay away from parsimonious accounts as farther as possible, and to enhance its sphere of impact by employing all persuasive techniques that may be influential. In another say, academic writings do not only simply produce plausible and strict accurate texts or knowledge, but construct a negotiation between the writer and reader through improving social relations.

\subsection{Discoursal features of the language used in writing and possible challenges}

Writing is an essential skill in every sphere of daily life. Whether it is used for simple or vital tasks, writing does not cease to be an indispensable component in the contexts where knowledge needs to be negotiated. Besides its steady influence over all types of documents from casual situations to top secret documents, writing has an exclusive and privileged position in scholarly writing for which academic writers aspire.

The process of productive and effective writing is not an easy task, and it is not uncommon for even the most veteran scholars to encounter challenges in the process of composing a text productively and 
effectively (McCormick \& Whittington, 2000; Hinkel, 2004; Meyer-Salager, 2008) because effective and productive writing desperately requires a well-organization and complete content knowledge. However, "Academic writers are not solely expected to produce texts that will conceivably represent an external reality, but to use language to offer a salient and dependable illustration of themselves and their work, and to establish social relations with readers through acknowledging and negotiating (Yağız, 2009, p. 42)", and this categorically requires the use of metadiscourse devices appropriately and proportionally.

There is no doubt that metadiscourse devices are crucial rhetorical devices that "represent a major contribution to the social negotiation of knowledge and writers' efforts to persuade readers of the correctness of their claims, helping them to gain community acceptance for their work" (Hyland, 2000, p. 89), but what is challenging for academics is writers should strike a balance in order not to be seen too rhetorical, which may harm objectivity of the academic writing. Accordingly, Dafouz-Milne (2008) found that academic texts with a true balance of rhetorical devices became more convincing in terms of audience persuasiveness. In short, rhetorical devices have a significant role in constituting central pragmatic features in the process of influencing, persuading, and engaging readers to assent to the writer's claims (Rubio, 2011). However what should be kept truly in the picture is that any immoderate and unbalanced use of these rhetorical devices could lead to a counter effect on writers' credibility in the readers' eyes.

\section{Gender and discourse}

At first flush, the relation between metadiscourse and gender might not be obvious or closely associated, but in reality authorial voice is profoundly in reciprocation with gender. Possibly for the first time, Robin Lakoff (1973) built a straightforward bridge between characteristics of women's language and linguistic forms through her study titled The logic of Politeness, and since then on the researchers have been attracted by the issue that might be investigated from a linguistic perspective.

The relationship between metadiscourse and gender can be investigated from many different perspectives such as politeness, face-saving, face-threatening, conversational contact, conversational maxims, social norms etc. Specifically, two subcategories of metadiscourse -hedging and boosting-were investigated heavily in linguistics to reveal gender impact on writing; for example, the very first research seems belonging to Holmes (1990) who studied hedges and boosters in men's and women's speech. Holmes ended that women and men have differentiated in style of speech, accordingly that women were more submissive while males more authoritative in the course of speaking.

The speaking style is not free from other external or internal conventions such as cultural, political, or even regional reasons. In other words, the high frequencies of hedges in a female conversation would not be correct to generalize to all female speakers in the world because as Dixon and Foster (1997) demonstrated that contextual influences have a crucial part in selecting words that will constitute the speaking style. Not only because contextual influences but other influences raging from religion to daily gender expectation are influential factors determining the speaking style of the speaker. Therefore, a study aiming to reveal gender differences in using rhetorical devices is to be conducted locally, and must be very tentative while generalizing the results acquired. Some studies studied metadiscourse devices more specifically through content-based investigations; for instance, role of interaction and stancetaking of academic authors were investigated on gender basis to be able to reveal mood and modality employed in Biology and Linguistic research papers (Aboulalaei, 2013) and results demonstrated that female authors slightly tended to metadiscourse devices more than males. Similarly, Vasilieva (2004) 
compared Russian male and female texts written in English, and found that amplifiers such as emphatic adverbs and certainty adverbs engrossed male texts more than they did female texts.

\section{Extra-linguistic factors affecting rhetoric}

The main source of difference seems related to the writer's nationality. Then, it turned out that knowledge of rhetoric may also be a reason of difference between authors. What is meant with "knowledge of rhetoric" does not refer to a situation in which a user has a degree of knowledge of rhetoric or metadiscourse indeterminacy from lexical or grammatical perspective, but refers to a situation the author is not aware of the importance of rhetorical strategies on readers. However, thanks to the researchers who examined the issue from varied perspectives by shifting their points of views, we know that there may be other factors affecting rhetorical features that the authors use. Accordingly, the present study detected other factors as social and intra-personal.

\subsection{Social factors}

Rhetorical strategies are not restricted to a certain set of factors because the influence of rhetorical strategies has a much more diameter than it used to be thought. As far as it is understood from this literature, social factors might be important in determining the writing style of an author. As regards the relationship between writing and the preferences of rhetorical devices, Connor (2004) stated that writing is increasingly considered as socially situated, and this socialization may give rise to special consideration to purposes, audience, level of perfection, and correspondingly may necessitate varying amounts of attention to detail, revision, and collaboration. Connor linked the use of rhetorical devices to the environmental powers occurring around, which is why contextual factors seemed crucial for her. Alike to Connor's propositions, Mauranen (2001) emphasized the assumption that "in order to arrive at an explanation of why texts the way they are, it is necessary to draw on the social contexts where they occur" (p. 45).

\subsection{Intrapersonal factors}

Particular emphasis was given to external influences of metadiscourse devices. Therefore, grave reservations may be expressed about argumentations that solely focus on environmental factors in terms of explaining differences or preferences among authors. In other words, of all factors which are offered as determinants on the use of rhetorical devices, intrapersonal factor is one of the major factors determining authors' way of addressing in the process of writing.

It is believed that the use of language carries some individualistic features affecting the authors' tone. Even the writer's personality is an important component in establishing his/her own discourse; being mild-tempered or being agitated affects the selection of vocabulary, the number of boosters as well as hedges, and hence the discourse.

Apart from the author's personality temper, emotional commitment to an issue may also be a determinant in terms of using rhetorical devices. The authorial stance towards a situation which the author finds affective might have a profound effect in constructing the meaning through rhetorical devices fluctuating between the overuse and underuse of certain rhetoric devices. In other words, it is possible an author to be akin to a point of view, and hence it is possible she/he shows a tendency to the side which she/he supports through the use of intensifiers. 
Other salient intrapersonal determinant is author's culture. Culture to be discussed here is different from the concept of culture discussed in the previous title in that intrapersonal culture is an issue concerning the cultural setting in which the author was raised while the concept of culture in the previous title pertains to the cultural setting that the author should be in tune with.

Except of social factors that affect the use of metadiscourse by authors, intrapersonal factors are also important determinants that determine the style of writing. Therefore, it had better authors be aware of such internal factors that may influence their language in the course of academic writing.

\section{Appropriate style of writing}

So far, it has been put forward that academic writing is affected by metadiscourse devices; accordingly, metadiscourse devices are affected by the gender, and finally the output of all these impacts emerges the writing style of the author. But is it necessary for an author of academic writing to strictly adhere to a certain style of writing? Of all writers who produce texts for different genres, academic writers are those who need to be very sure about appropriateness of their communication. It is definitely true that the style of a particular text must be consistent, but to be proper for the audience as well as the message being conveyed is the other convention of even a simple piece of writing. The use of correct vocabulary (formal or informal), the jargon that the text written with, competence of grammar, moderate complexity, conciseness etc. are the very prevailing factors that are known by almost all writers in academe; however, not all are limited to them as the recent developments on stylistic have obviously put forward.

The literature has provided some windows on stylistic appropriateness in academic writing. The stylistic appropriateness was used to be related to the successful use of vocabularies, grammar or complexity of the sentences, but it seems that there is a certain steering from, what used to be mechanical accuracy towards rhetorical competence, which necessitates meticulous discourse equilibrium without being too assertive or too unpretentious. No matter how complex data or authentic propositions an academic text has, any piece of writing that cannot perform rhetorical strategies in appropriate manner may not create the desired effect, and may be considered of no use. Therefore, not to have a non-academic style, scholars should take the vitality of metadiscourse devices into consideration.

On the other hand, assertiveness, degree of formality, and politeness strategies are not stable elements of style in every setting; to the contrary, they vary from one culture or language to another (BardoviHarlig, 2001). In other words, the common habits of discourse among nations are not exactly the same. In other words, depending on the contexts, nationalities, background knowledge, or culture, academic writers show similar tendencies in their writing styles. But, academic writers need to be independent from national, personal, and psychological influences, and need to agree with the rules regarding rhetorical strategies if the focus is reader persuasion over the preposition.

\section{Conclusion}

The language of science should bear some attributes for a good scientific writing. "Clarity in scientific writings, objectivity in scientific writings, and accuracy in scientific writings" are three basic accepted qualifications which cannot be ignored in the process of scholarly writing. There are certain dos and don'ts which authors should not miss in the process of composing a scientific text; whether it is an empirical or conceptual study. Shortly, the thing which is common among all types and classes of 
academic writing is the fact that the ideas seize the centre stage, human factor is in the background, and the representation of any ideas or insights belonging to the author has no place (Monippally \& Pawar, 2010). Objectivity, clarity, accuracy, and other crucial components of academic writing have two basic goals: "to establish the truth", and "to convey the knowledge". It is possible for a text to bear all the musts of being scientific, and yet, not successful to create the desired effect on the readers.

There are some other invisible but potent conventions of a scientific writing; for example, rhetoric powers of words. Although metadiscourse has a wide area of influence in a writing text, it seems as if it was always the content of a paper which is the most important. In line with this, rhetorical devices are generally overlooked in the books aiming academic writing trainings and suggestions (exceptions Hinkel, 2004; Hyland, 2005). Therefore, together with impersonal style, accuracy, clarity and other features of academic writing, rhetorical devices should also be mentioned strictly. While reporting research results or making claims, writers must decide on the language they would use.

Gender is an important factor for the language of academic writing. Numerous studies show the correlation between gender and the tone of the language, which is women prefer to communicate more indirectly while men prefer more direct way of writing. Furthermore, the level of formality is higher with female writers when compared to male writers (Holmes, 1995). Writers who aim to conduct a study on discourse should not overlook the effect of gender, and should be aware of the possible impact of it on the results; therefore, this study suggests writers to collect their data on gender-based distinction so that there will not be a reliability problem regarding the data, and accordingly the results. Accordingly, although there are not many a few studies on, it is seen that not only gender but also extralinguistic factors have an effect on the style of writing; especially social and intra-personal factors leave a mark on your writing.

This study establishes a link among gender, metadiscourse and writing style, and claims that the style of writing cannot be independent of their effects. Further studies may search the effect of gender on more specific linguistic components in order to reveal rhetoric differences. Similarly, this study puts forward the effect of social and intra-personal factors on writing style while there may be some other extralinguistic factors affecting the style of writing such as other pragmatic factors.

\section{References}

Aboulalaei, M. H. (2013). Exploring the Differences Between Iranian Women and Men Academic Article Writings According to Mood and Modality. Middle-East Journal of Scientific Research, 18(5):668-674, doi:10.5829/idosi.mejsr.2013.18.5.11757.

Allison, D., Cooley, L., Lewkowicz, J., \& Nunan, D. (1998). Dissertation writing in action: The development of a dissertation writing support program for ESL graduate research students. English for Specific Purposes, 17(2), 199-217.

Argentina, M. V. (2013). Some Tips For Teaching L2 Academic Writing. Humanising Language Teaching, 15 .

Atkinson, D. (1999). Scientific Discourse in Sociohistorical Context. Mahwah, NJ: Lawrence Erlbaum.

Bailey, S. (2006). Academic Writing (2nd edition). Oxon: Routledge.

Bailey, S. (2011). Academic Writing (3rd edition). Oxon: Routledge.

Bardovi-Harlig, K. (2001). Evaluating the empirical evidence: grounds for instruction in pragmatics? In K. Rose, \& G. Kasper, Pragmatics in Language Teaching (pp. 13-32). Cambridge: Cambridge University Press. 
Bunton, D. (1999). The use of higher level metatext in PhD theses. English for Specific Purposes, 18, 4156.

Connor, U. (2004). Intercultural rhetoric research: Beyond texts. Journal of English for Academic Purposes, 3:291-304, doi:10.1016/j.jeap.2004.07.003.

Crismore, A. (1989). Talking with Readers: Metadiscourse as Rhetorical Act. New York: Peter Lang.

Crismore, A., \& Farnsworth, R. (1990). Metadiscourse in popular and professional science discourse. In W. Nash, The Writing Scholar: Studies in Academic Discourse (pp. 118-36). Newbury Park, CA: Sage.

Dafouz-Milne, E. (2008). The pragmatic role of textual and interpersonal metadiscourse markers in the construction and attainment of persuasion: A cross-linguistic study of newspaper discourse. Journal of Pragmatics, 40, 95-113.

Dixon, J. A., \& Foster, D. H. (1997). Gender and Hedging: From Sex Differences to Situated Practice. Journal of Psycholinguistics Research, 26(1): 89-107, doi:10.1023/A:1025064205478.

Fuertes-Olivera, P., Velasco-Sacristan, M., Arribas-Bano, A., \& Samaniego Fernandez, E. (2001). Persuasion and advertising English: metadiscourse in slogans and headlines. Journal of Pragmatics, 33, 1291-1307.

Fulwiler, T. (2002). College Writing (3rd Edition). Portsmouth, NH: Boynton/Cook Publishers, Inc.

Hauser, G. (1986). Introduction to Rhetorical Theory. New York: Harper.

Hinkel, E. (2003). Simplicity without elegance: Features of sentences in L1 and L2 academic texts. TESOL Quarterly, 37(2), 275-301.

Hinkel, E. (2004). Teaching Academic ESL Writing. New York: Routledge.

Hirose, K. (2003). Comparing L1 and L2 organizational patterns in the argumentative writing of Japanese EFL students. Journal of Second Language Writing, 12, 181-209.

Holmes, J. (1990). Hedges and Boosters in Women's and Men's Speech. Language \& Communication, 3:185-205, doi:10.1016/0271-5309(90)90002-S.

Holmes, J. (1995). Women, men and politeness. London: Longman.

Hyland, K. (1998). Persuasion and context: the pragmatics of academic metadiscourse. Journal of Pragmatics, 30, 437-55.

Hyland, K. (2000). Disciplinary Discourses: Social Interactions in Academic Writing. London: Longman.

Hyland, K. (2004). Disciplinary interactions: metadiscourse in L2 postgraduate writing. Journal of Second Language Writing, 13: 133-51.

Hyland, K. (2005). Metadiscourse: Exploring Interaction in Writing. New York: Continuum.

Hyland, K. (2006). Disciplinary differences: Language variation in academic discourses. In K. Hyland, \& M. Bondi, Academic Discourse across Disciplines (pp. 16-45). Berlin: Peter Lang.

Hyland, K., \& Milton, J. (1997). Qualification and certainty in L1 and L2 students' writing. Journal of Second Language Writing, 6(2), 183-205.

Hymes, D. (1974). Foundations in Sociolinguistics: An Ethnographic Approach. Philadelphia: University of Pennsylvania Press.

Lakoff, R. (1973). The logic of politeness: or, minding your p's and q's. In C. C. al., Papers from the ninth regional meeting of the Chicago Linguistic Society (pp. 292-305). Chicago: Linguistic Society.

Mauranen, A. (1993). Cultural Differences in Academic Rhetoric. Frankfurt: Peter Lang.

Mauranen, A. (2001). Descriptions or explanations? Some methodological issues in Contrastive Rhetoric. In M. Hewings, Academic Writing in Context: Implications and Applications (pp. 4354). Birmingham: University of Birmingham Press. 
McCormick, D., \& Whittington, M. S. (2000). Assessing academic challenges for their Contribution to cognitive development. Journal of Agricultural Education, 41(3):114-122.

Meyer-Salager, F. (2008). Scientific Publishing in developing countries: Challenges for the future. Journal of English for Academic Purposes, 7(2):121-132.

Monippally, M., \& Pawar, B. S. (2010). Academic writing; a guide for management students and researchers. New Delhi: Response.

Munby, J. (1978). Communicative Syllabus Design. Cambridge: Cambridge University Press.

Norrick, N. R. (2001). Discourse markers in oral narratives. Journal of Pragmatics, 33, 849-78.

Ong, W. (1983). Foreword. In W. B. Homer, The Present State of Scholarship in Historical and Contemporary Rhetoric (pp. 1-9). Columbia, MO: University of Missouri Press.

Richards, J. C., \& Miller, S. K. (2005). Doing Academic Writing in Education. New Jersey: Taylor \& Francis.

Rubio, M. M. (2011). pragmatic approach to the macro-structure and metadiscoursal features of research article introductions in the field of Agricultural Sciences. English for Specific Purposes, 30, 258-271.

Schiffrin, D. (1980). Metatalk: organisational and evaluative brackets in discourse. Sociological Inquiry: Language and Social Interaction, 50:199-236.

Shi, L. (2002). How Western-trained Chinese TESOL professionals publish in their home environment. TESOL Quarterly, 36(4), 625-634.

Smyth, T. R. (1996). Writing in psychology: A student guide. New York: Wiley.

Swales, J. (1990). Genre Analysis: English in Academic and Research Settings. Cambridge: Cambridge university press.

Taavitsainen, I. (1999). Metadiscursive practices and the evolution of early English medical writing (1375-1550). In J. M. Kirk, Corpora Galore: Analyses and Techniques in Describing English (pp. 191-207). Amsterdam: Rodopi.

Van, J. C. (2015, 5 18). Retrieved from http://www.public.asu.edu: http://www.public.asu.edu/ jvanasu/rhet-triangle.htm

Vande Kopple, W. (1985). Some exploratory discourse on metadiscourse. College Composition and Communication, 36, 82-93.

Vasilieva, I. (2004). Gender-specific Use of Boosting and Hedging Adverbs in English Computer-related Texts- A Corpus-based Study. International Conference on Language, Politeness and Gender (pp. 2-5). Helsinki, Finland: University of Helsinki.

Weida, S., \& Stolley, K. (2013, 03 11). Using Rhetorical Strategies for Persuasion. Retrieved from https://owl.english.purdue.edu/owl/resource/588/04/

Williams, J. (1981). Style: Ten Lessons in Clarity and Grace. Boston: Scott Foresman.

Yağız, O. (2009). The Academic Writing of Turkish Graduate Students in Social Sciences: Approaches, Processes, Needs and Challenges (PhD dissertation). tez.yok.gov.tr: 241779. 